\title{
Artelogie
}

Recherche sur les arts, le patrimoine et la littérature de l'Amérique latine

$3 \mid 2012$

Image de la nation : art et nature au Chili

\section{Desfiguraciones del exilio en "El Eco de las} canciones", de Antonia Rossi

Fernanda Carvajal

\section{OpenEdition}

\section{Journals}

Edición electrónica

URL: https://journals.openedition.org/artelogie/7466

DOI: 10.4000/artelogie.7466

ISSN: 2115-6395

\section{Editor}

Association ESCAL

Referencia electrónica

Fernanda Carvajal, «Desfiguraciones del exilio en "El Eco de las canciones", de Antonia Rossi», Artelogie [En línea], 3 | 2012, Publicado el 12 septiembre 2012, consultado el 07 enero 2022. URL: http://journals.openedition.org/artelogie/7466 ; DOI: https://doi.org/10.4000/artelogie.7466

Este documento fue generado automáticamente el 7 enero 2022.

Association ESCAL 


\title{
Desfiguraciones del exilio en "El Eco de las canciones", de Antonia Rossi
}

\author{
Fernanda Carvajal
}

Nota: Agradezco a Pio Longo sus valiosos comentarios a este texto.

1 Tras el Golpe de Estado de 1973, miles de chilenos, en ocasiones familias enteras, fueron exiliadas por la dictadura de Augusto Pinochet. El documental de Antonia Rossi, El eco de las canciones trabaja sobre la memoria del exilio, más precisamente, sobre la memoria de quienes, como la propia directora del film, nacieron y fueron niños en situación de destierro político. Se trata por tanto de una película que borda y aborda situaciones biográficas atravesadas por la irresolución del lugar propio. De quienes, frente la experiencia del retorno, deben entrar en relación con un territorio extraño que les ha sido asignado por herencia. De este modo, el documental nos enfrenta a un relato sobre las ambigüedades que surgen ante la imposibilidad de una relación lineal entre geografía, nacimiento y pertenencia, abriendo un espacio de extrañamiento y trastorno de las imágenes y mitos de la nación anclados al período dictatorial.

Como señala un comentario sobre la película publicado en un blog, El eco de las canciones, "No parece una película chilena. Y es tan extraño que no lo parezca porque el

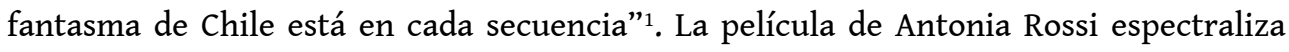
una imagen de Chile pues gira sobre la dificultad para estabilizar una imagen del territorio chileno como paisaje habitable; enrarece y desacraliza la iconografía y los signos identitarios con los que la cultura del exilio chileno añora una comunidad que es vista como lejana y enaltecida. Se trata de un film que desde anclajes históricos precisos (lo que más adelante llamamos una “cronología emblemática” del régimen militar), logra desviar ciertos tópicos del exilio político durante la dictadura.

Los procedimientos formales consisten en un particular ensamblaje entre voz y montaje. A lo largo de todo el film escuchamos una voz femenina que va y viene entre su indagación sobre el pasado y su relato del presente, reflexionando sobre las desfiguraciones y fabulaciones liberadas por los orificios de la memoria ${ }^{2}$. Hay pues indicios de lo autobiográfico, una decisión de construir una primera persona narrativa, que relata su vida (a partir del exilio de los padres a Italia) asumiendo un modo 
reflexivo, un registro casi literario, que irá conduciendo el relato del film a través de una palabra que se da en un registro poético antes que en la economía de del argumento. Aún así, el género autobiográfico es fisurado al tratarse de una voz que no sólo no tiene rostro, si no que no tiene nombre. Hay una renuncia al nombre como acto inaugural de la identidad que inicia al sujeto en el tiempo del lenguaje y que pone en funcionamiento una acumulación y retención de huellas que serán suscritas a un yo. Es posible pensar entonces que en la renuncia al nombre hay una renuncia a la unidad del "yo" como objetivo último de la autobiografía.

4 Esa voz acusmática sin nombre, que opera en la película como la insistencia en un personaje, entra a la vez en tensión con la política de montaje del film que hace proliferar y desplaza las marcas de una identidad unificada. En efecto, el montaje ensambla una serie de documentos visuales y sonoros: filmaciones familiares, fotografías, postales de viajes, películas de ficción y animación, publicidades, material de cámara que muestra el Santiago de los años 80s, filmaciones actuales de Santiago, imágenes de archivos televisivos, registros radiofónicos de época que aluden a hechos históricos precisos y múltiples texturas de sonidos que hacen reverberar el encuadre visual. A medida que el film avanza, entendemos que los materiales visuales que vemos pasar en la pantalla, no corresponden al cúmulo de registros biográficos de una sola persona ${ }^{3}$. Se trata en suma, "de una voz que no tiene dueño"4.

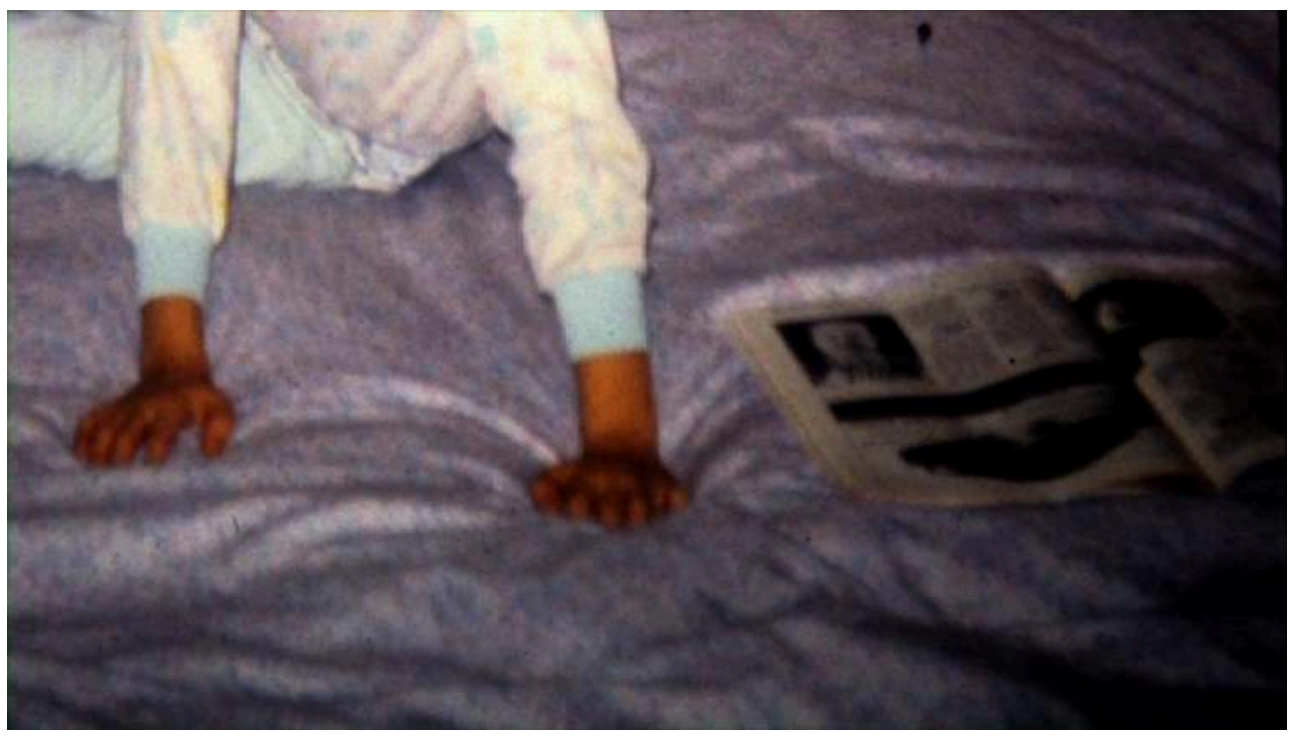

5 A dicha voz ficcionada, que no pertenece a ningún sujeto biográfico "real", se la dota de una subjetividad al superponerla a una serie de imágenes, fotografías y documentos audiovisuales que la inscriben en la vida de un "alguien" y en la historia de un país: Chile. Este uso de la voz que intenta inscribir los materiales de archivo en una duración, acerca al film a nociones de la biopolítica al "mostrar como lo vivo puede ser sustituido por lo artificial y como lo artificial puede ser convertido en vivo mediante la correspondiente narración" (Groys, 2008: p. 175). De este modo, El eco de las canciones ensambla una serie de retazos documentales para producir la ficción del relato de una vida en la cual confluyen huellas biográficas de otros y al mismo tiempo evidencia cómo una vida como tal, en su duración, no puede ser nunca mostrada (sólo pudo ser documentada). En efecto, en el proceso de creación del film, la directora recogió un conjunto de testimonios a hijos de exiliados que nunca fueron pensados como entrevistas en plano, pero que de una $u$ otra forma componen el relato del film. En esa 
vida que se nos dice mostrar, resuenan entonces muchas otras, reverbera el eco de múltiples voces, y el film se introduce entonces en el terreno indecidible entre lo singular y lo plural, lo individual y lo colectivo, entre lo íntimo y lo histórico.

Desde ahí, es factible plantear que la película de Rossi toca y a la vez se desmarca del género testimonial. La voz que recorre el film no construye su enunciación a partir de la certificación de los hechos y datos de su discurso, tampoco es un film que tome como premisa la autoridad epistémica de las imágenes para mostrar el pasado que fue. Más bien trabaja sobre el supuesto de que no es posible mostrar el pasado, sólo es posible construir (incluso fabular) ese pasado que no veremos a partir de sus huellas. Ello no implica que no se puedan rescatar puntos de verdad sobre el pasado. Sino que esa verdad no se sostiene en la puesta en evidencia de un discurso, y más bien irrumpe justamente en la fisura que separa la construcción del sentido, lo real referencial y la heterogeneidad de sus documentos (Ranciere, 2005). En lo que sigue, intentaremos ir rastreando algunos de estos momentos de verdad que el film despunta.

\section{Catástrofes o la imposibilidad del paisaje}

7 En su acepción más común, la palabra exilio alude al abandono forzado de un territorio, un movimiento de salida de lo propio. La fuerza de atracción de lo propio estaría asociada a atribuciones de pertenencia ligadas a las ya tan discutidas figuras del origen: no sólo a la tierra, si no también a la sangre y la lengua. Entonces, entendido como movimiento de salida de lo propio, el exilio remitiría a una situación de pasaje: "el exilio como pasaje que preludia y prepara un regreso" 5 . Desde este enfoque, hablar del exilio pareciera siempre implicar hablar de una falta, de eso que se perdió ante la partida impuesta. Sin embargo, la película de Antonia Rossi se focaliza en la situación de extrañamiento que trae consigo el desarraigo de aquellos que nacen en el exilio, los que no salen de lo propio, sino que nacen ya en un "pedazo de tierra prestada" $\mathrm{y}$ crecen en la inminencia del regreso a un lugar prohibido, desconocido y hostil, que les corresponde por atadura de sangre, por filiación. Ahora bien, más allá de esta particularidad generacional, en la perspectiva del film el círculo del exilio pareciera no cerrarse en el retorno y la cuestión de la pertenencia queda descentrada y volcada hacia un lugar por-venir.

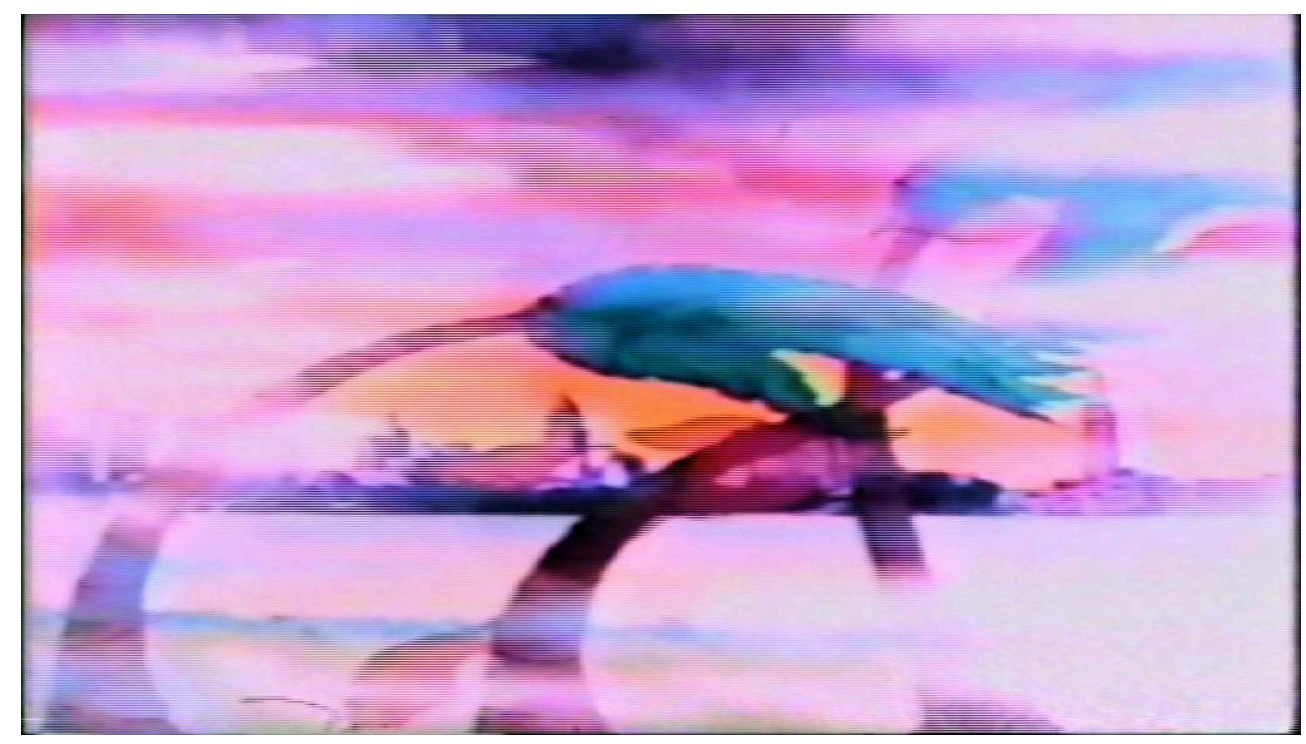


8 En este sentido, se torna particularmente interesante abordar la relación entre territorio, naturaleza y exilio trabajada en la película. Si hay una dialéctica entre sujeto y geografía cuyo territorio mediador es el paisaje, desde cierta perspectiva, el exilio podría ser entendido entre otras, como una pérdida del paisaje. En efecto, el paisaje suele funcionar como dispositivo de construcción del territorio nacional. Sin embargo, en $\mathrm{El}$ Eco de las canciones, las figuras de lo natural no aparecerán para reponer un espacio nativo reconocible, que correspondan a una idea de habitabilidad, a una naturaleza domesticada, apropiada, familiar. Lo más similar a un paisaje, son las postales de viajes por países lejanos, no identificados. La Cordillera, emblemático ícono que suele ser convocado a la restitución de Chile como territorio, aparece de manera furtiva, en un par de imágenes apenas retenibles (minuto 7:47, minuto 54:53).

9 En El eco de las Canciones, las imágenes de la naturaleza, no operan como remisión a lo oriundo, porque el territorio no es algo a recuperar si no algo a lo que todavía hay que dar forma, algo todavía por encontrar. Esta dificultad no ocurre sólo porque algunas de las representaciones de la naturaleza que aparecen no son imágenes de Chile si no de viajes, o porque algunas de ellas son "artificiales" (animaciones), si no porque cuando lo natural aparece, se trata más bien de la naturaleza como fuerza violentamente desencadenada (tormentas, huracanes, inundaciones) que impide estabilizar el territorio en paisaje, desnaturalizando y espectralizando a Chile como lugar.

Así, por ejemplo, el trazado de Chile en un mapa en el que los países aparecen como islas sin continente, brinda una imagen cartográfica del territorio que aparece para indicar el trayecto del exilio hacia Italia. Quizás por ello una de las pocas imágenes documentales no urbanas que aparecen del territorio chileno, es la imagen de los campos de hielo sur, que hablan de Chile como un territorio remoto, rodeado de agua, como una isla? .

11 El Archipiélago Patagónico, uno de los bordes del territorio nacional continental, representa en el imaginario un territorio virgen y a la vez inhóspito, un paraje embestido por violentas tormentas y ráfagas de viento, dotado de un clima y una naturaleza ingobernables, que brindan "imborrables sensaciones de un mundo de caos" (Martinic, 2004: 23). Como señala Martinic, se trata de un territorio que no muestra "rasgos humanizados en su paisaje, propios de una acción antrópica permanente y modificadora de la naturaleza" (258). Los campos de hielo sur serían "un distrito paradojalmente ajeno en un territorio propio" (10), un lugar que puede ser navegado, pero no habitado por el hombre moderno que "sólo ha tenido y tiene el carácter de mero transeúnte" (258, subrayado en el original).

Por otra parte, la imagen del desierto, que retorna una y otra vez en el film, opera como una imagen-espejismo: no se trata en ningún caso del desierto atacameño, andino, si no del desierto del imaginario orientalista, con camellos y tribus nómades. Estas imágenes encuentran resonancia en las imágenes documentales de los campamentos instalados a la interperie tras el terremoto del 1985 en Santiago de Chile (minuto 22:54). De modo que aquellas imágenes del desierto no sólo operan como imágenes sensibles de lo inhóspito y la errancia, si no que de alguna manera prefiguran la hostilidad de un país azotado por terremotos y migraciones internas, un "país joven pero repleto de ruinas" (Castillo, 2004: p. 139), que por momentos se asemeja más a la aridez de un campamento minero (como muestras las vistas aéreas de los alrededores de Santiago, minuto 60:00) que a la promesa de una naturaleza desbordante. 


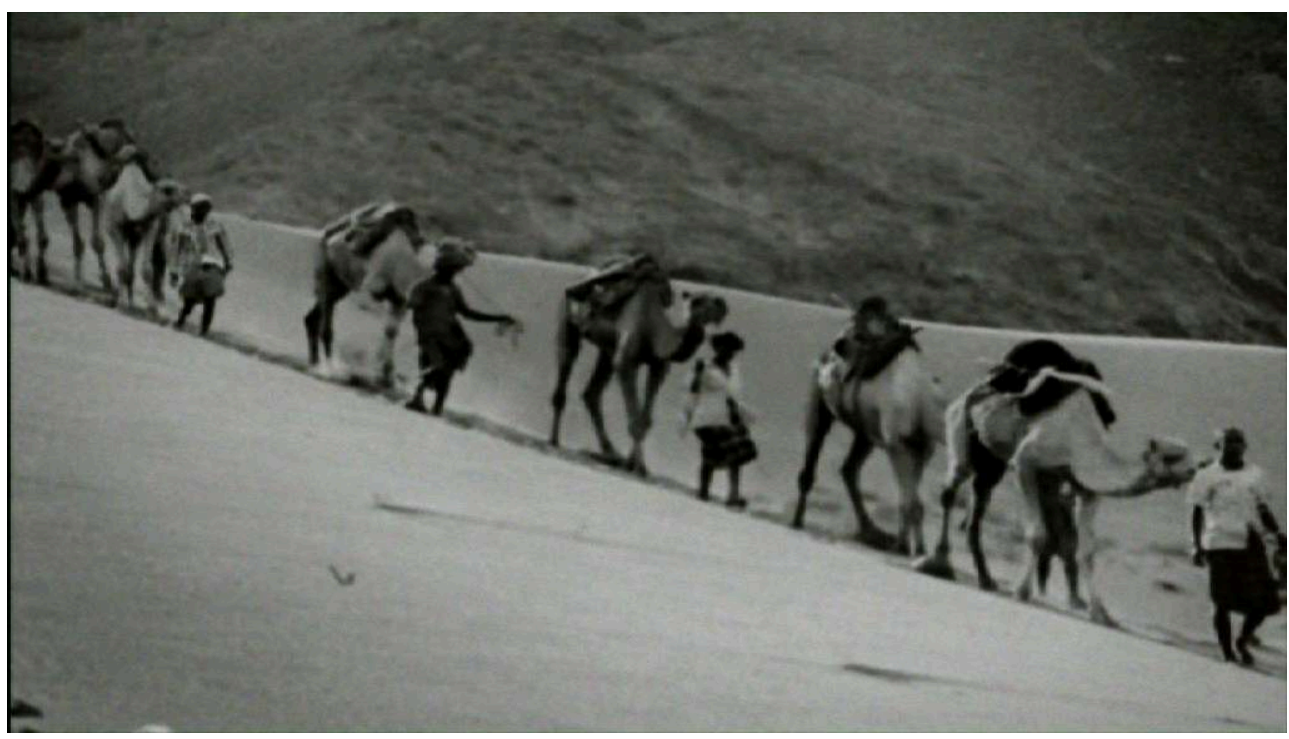

El desastre natural es un tópico ya recurrente en el imaginario representacional de Chile que ha convertido la catástrofe en un modo de lo social y en una forma de conciencia trágica ${ }^{8}$. La figura de la catástrofe como trastorno inesperado de una geografía que deviene loca ${ }^{9}$, como aquello que separa de sí a la naturaleza, podría ser vista como modelo de transformaciones irreversibles de la estructura social. Dicho de otra manera, la catástrofe como figura de la naturaleza, invoca la historia como su propio fuera de campo. De modo que es posible pensar que las imágenes de caos desatado por la naturaleza que aparecen en el film, aparentemente autónomas y autosuficientes, se cargan de significación a través de lo que el desastre natural supuestamente excluye: el conflicto histórico (Golpe de estado de 1973). Así en la película, como veremos en un siguiente apartado, catástrofe histórica y catástrofe natural parecen codificarse mutuamente. Es como si en lugar de las figuras del origen (sangre, territorio, lengua) la película situara en el comienzo la catástrofe. No por nada, un navegante como Gulliver es una figura que recorre toda la película como una alteridad de la voz, tal como queda trazado desde el comienzo del film cuando la imagen del despertar de Gulliver tras su naufragio (el despertar tras las catástrofe) coincide con el de la voz en su relato (y aquí la cuestión del naufragio no será banal, como notaremos más adelante). 


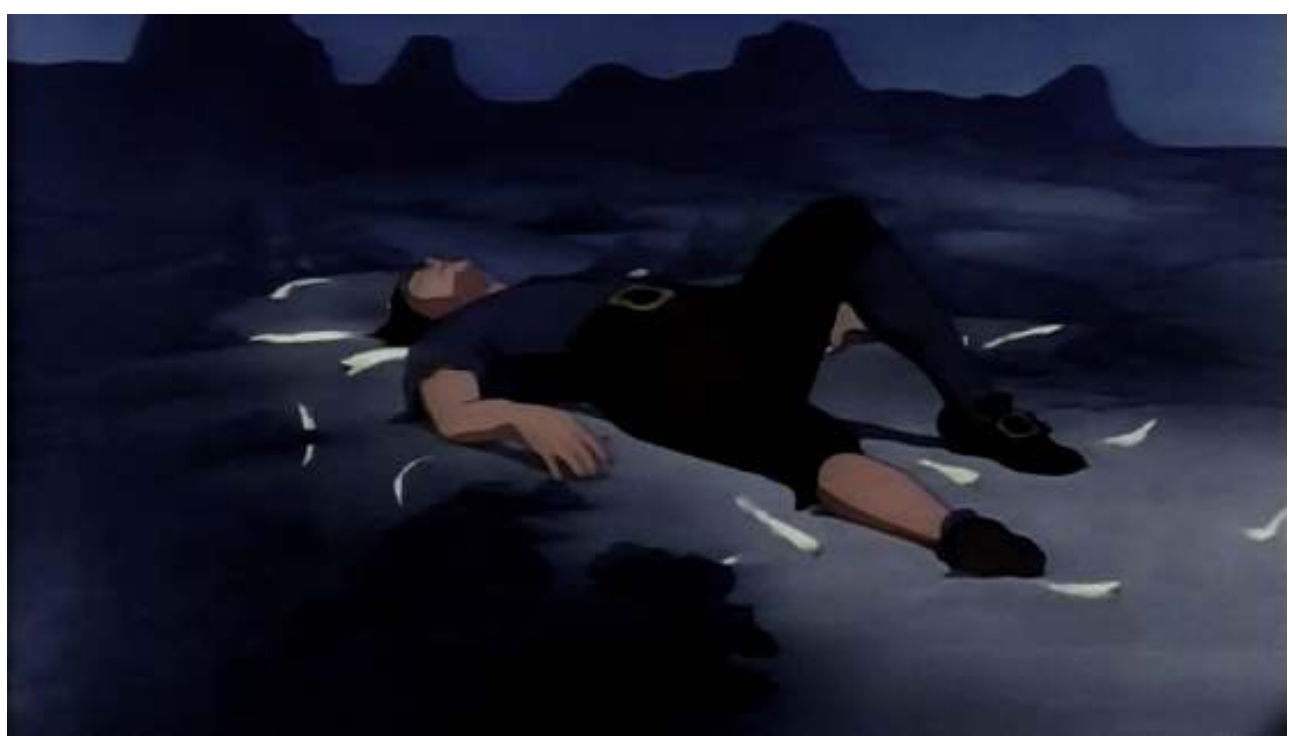

Si en general las memorias del exilio trabajan sobre un movimiento hacia el origen, hacia la recuperación de lo expropiado y el rencuentro con lo perdido, El Eco de las canciones se introduce más bien en la experiencia del desplazamiento y la salida sin origen. Desde estos presupuestos, la película de Rossi trama el relato de la perturbación a los cimientos de la identidad que trae consigo la ruptura de la ligazón entre nacimiento y territorio, explorando las sinuosidades de la pertenencia como ajenidad. El filme se introduce así en zonas que contienen y a la vez desbordan, como veremos, el problema de la dictadura como motivo.

\section{La opacidad de lo familiar}

El eco de las canciones produce un corrimiento respecto a los abordajes previos que el cine chileno nos ha entregado sobre el exilio, al poner en relación exilio e infancia y construir una memoria del exilio que parece venir de la lucidez del sueño antes que del imperativo racional de la vigilia.

La investigadora Loreto Rebolledo (2006) ha apuntado como las memorias emblemáticas del exilio chileno, parecieran inmovilizarse en torno a dos grandes tópicos. Por un lado, la melancolía por lo perdido: la patria que se deja y la derrota política. Por otro, un discurso anclado en la culpa, por haber sobrevivido, por abandonar la lucha contra el régimen. En contraste y quizás por pertenecer a la generación de los hijos de aquellos que se vieron forzados al exilio, la película de Antonia Rossi no apela a las retóricas de la denuncia, la reivindicación o la derrota para elaborar su relato sobre el pasado, que no se estructura en torno a la visibilización del dolor de las víctimas, ni tampoco en relación a la mitificación del pasado de la izquierda.

17 Sin minimizar ni eludir el contexto de la dictadura El eco de las canciones pareciera rodear o aludir de manera oblicua estos imaginarios que de manera tan pregnante se han arraigado al período dictatorial, llegando incluso a inmovilizar los constructos discursivos sobre una época.

18 En este sentido, la conexión entre exilio e infancia, será un nudo central en el desplazamiento de las memorias emblemáticas del exilio. Desde cierta perspectiva, la 
infancia aparece como un estado germinal y difuso, en busca del lenguaje (etimológicamente el infante es "el incapaz de hablar"10), como un hiato habitado por el relato del otro (y los otros) que deviene así enigma de la propia biografía. El exilio, esa salida forzada de lo propio de aquél que es empujado a devenir extranjero, tiene en común con la infancia la falta respecto al habla oficial, y también una suerte de falta de ciudadanía. Como ha señalado Giorgio Agamben, el exiliado habita el corte del vínculo entre nacimiento y territorio en el que se funda la soberanía y en este sentido sería un "abandonado por la ley". De modo que más allá de las distintas figuras que el exilio pueda asumir, parecería no ser claramente ni una pena ni un derecho ${ }^{11}$.

El niño y el exiliado tienen un estatuto civil restringido, que en el caso del exiliado, aplica tanto al lugar donde transcurre el exilio, como en el país que se abandona forzosamente y al que luego se retorna. Y en el caso del niño, implica una ciudadanía en limitada y bajo custodia, aún sin agencia propia. El eco de las Canciones retoma y trabaja en esta frontera compartida por el niño y el exiliado, en la que ocurre una la alteración de las referencias simbólicas, espaciales e históricas que puede llegar a modificar de manera decisiva la relación entre lo propio y lo ajeno.

Ahora bien, si desde el discurso dominante, infancia y exilio, más aún, la cuestión de la infancia en el exilio, pueden aparecer como tiempos suspendidos, como brechas acotadas de la propia biografía, por el contrario, en la película de Antonia Rossi el tiempo biográfico parece desdoblado de modo tal que la infancia no emerge como aquello que se deja atrás, si no que presupone cierta contemporaneidad entre la adultez que rememora desde el presente y la niñez como otro que adviene hacia su propia adultez. Rossi elabora de tal modo su personaje que en él se cuestiona la división tajante entre adultez e infancia y las jerarquías de la experiencia que dicha división lleva implícita, mostrando cómo ciertos modos de codificación y percepción que suelen ser asociados a la niñez constituyen claves de pensamiento que no son privativos de otros momentos biográficos.

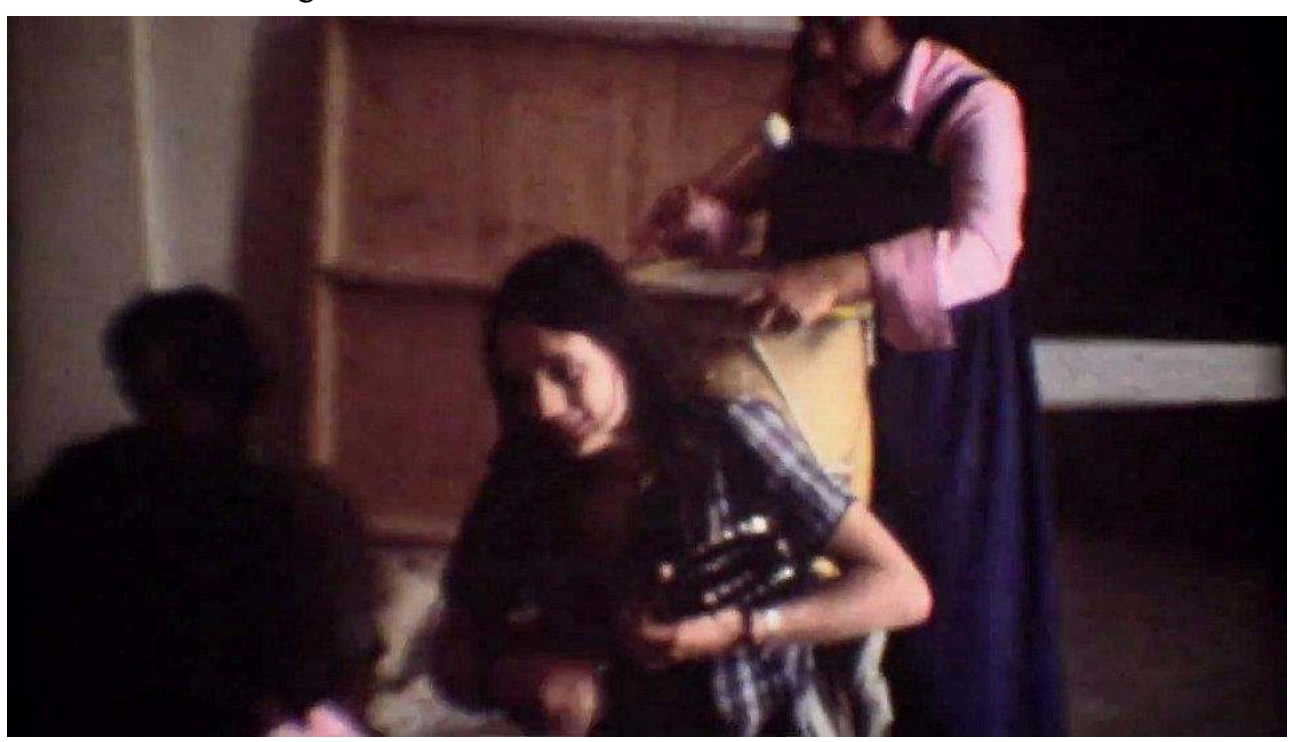

21 Así sucede con los registros de imágenes caseras y de películas de animación que suelen codificarse de un modo despolitizado con el universo de lo doméstico-familiar y de la infancia, respectivamente.

El conjunto de imágenes domésticas incluidas en el film, constituyen parte del repertorio de las imágenes no vistas del exilio, arrojando luz sobre el espacio 
experiencial de lo íntimo: una suerte de backstage del exilio, que no calza con las imágenes políticamente correctas del destierro político. Los archivos domésticos de nacimientos, viajes y fiestas funcionan como contra-escenas, porque (y a pesar de que) muestran los hitos y rituales celebratorios de una vida que parecen atemporales, lo que paradójicamente las impregna de una perturbadora opacidad. Pues las filmaciones caseras muestran una oposición entre tiempo personal y tiempo histórico al punto que pareciera que en épocas de convulsión y drama histórico (tales como la situación de destierro forzado), las filmaciones domésticas seguirían mostrando "felices" momentos familiares. Como señala van Alphen, las filmaciones domésticas, en especial en el período previo a la era digital, muestran acontecimientos que se reiteran de una familia a otra: bodas, nacimientos, reuniones y celebraciones. Son filmaciones que resaltan la dimensión afectiva de las imágenes "tratan sobre la vitalidad, sobre la diversión, sobre actividades como jugar y bailar" (van Alphen, 2009: p. 32) y los sucesos tristes o violentos, simplemente parecieran "no tener sitio en el dominio representacional de este género" (van Alphen, 2009: p. 44).

Aún así, a través de pequeños indicios, las imágenes cotidianas del exilio incorporadas en la película rasgan por momentos esa opacidad que parece obliterar el conflicto histórico. Si bien es cierto que a lo largo del filme vemos archivos domésticos de nacimientos, reuniones familiares y bailes que parecieran no hablar por si mismos de la situación de exilio, algunas imágenes dejan filtrarse indicios de la situación históricopolítica del destierro.

En la primera de ellas, vemos a una mujer que en medio de un ágape familiar es sorprendida por una cámara de video cuando una voz masculina le pide que envíe unas palabras a Chile. La imagen capta a la "señora María" en la espontaneidad de su gesto, que en un parpadeo, oscila entre la sospecha y la seducción. Ya controlando la situación, la mujer habla a cámara dirigiéndose a aquellos que no están ahí presentes, de modo que el registro de la fiesta queda descalzado de su función habitual, para devenir saludo y mensaje. La opacidad del registro familiar de la celebración navideña deja traslucir por un momento la experiencia de una distancia involuntaria, que se asoma de modo más evidente cuando la mujer explicita las "ganas de volver" y al mismo tiempo, da cuenta de lo específico de la mirada a cámara en las películas caseras: la indistinción que hay entre la cámara y la persona detrás del aparato ${ }^{12}$.

Entre estos archivos hay por cierto algunas imágenes de lo que sería esperable ver en un documental sobre el exilio: fragmentos en super 8 nos muestran lo que parece una reunión política de exiliados. Las paredes están cubiertas con múltiples afiches: posters de festivales de canto nuevo diseñados con gráfica setentista donde podemos leer consignas políticas, papelógrafos que muestran fotos de desaparecidos políticos, afiches de peñas, de amnistía internacional: iconografía propia de la cultura del exilio latinoamericano. Sin embargo, lo que vemos no son personas en actitud de mitin político, sino los tiempos muertos de un encuentro, hombres que realizan gestos infantilizados, que sonríen, levantan y giran las manos para saludar a la cámara (minuto 10:35) tal como el juguete antiguo que mueve sus brazos en forma de un saludo que vimos hace un momento en la misma secuencia (minuto 10:12). 


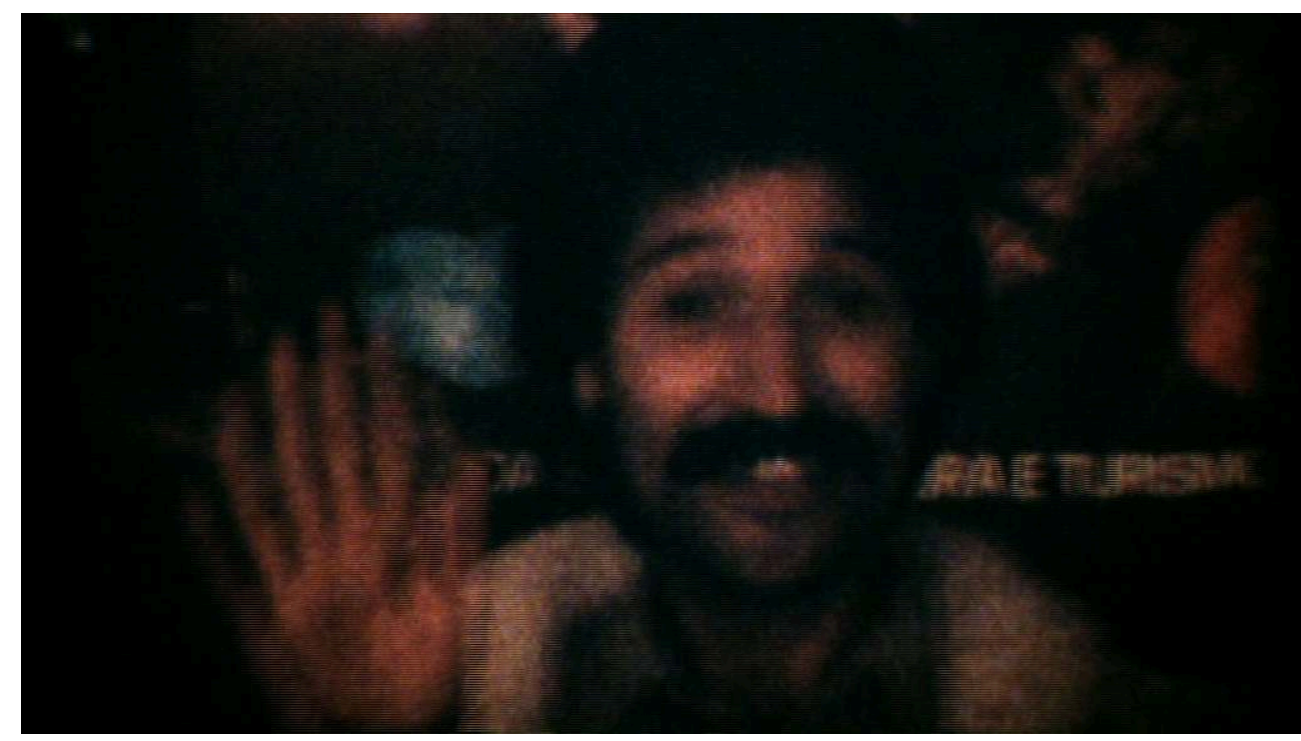

Entre los registros domésticos de imágenes de exiliados, vemos una escena musical: una mujer toca el bombo y otra el charango (aunque la melodía que escuchamos no se corresponde a la de esos instrumentos) y en contraplano, un grupo de personas bailan dando giros sobre sí mismos revoleando pompones andinos y dibujando un espacio circular, en lo que parece ser la coreografía de una danza típica latinoamericana (minuto 8:30). Como un recuerdo que se desdobla, este fragmento establece un ritornello en las animaciones en blanco y negro que muestran una hilera de siluetas humanas espectrales, sonámbulas, que giran sobre sí mismas mientras un payaso toca el tambor, abriendo así un universo vinculado a lo siniestro (minuto 22:00).

Las imágenes de juguetes y animaciones de luz y sombra aparecen así como contraseñas que dan legibilidad ambigua a íconos idiosincráticos, que aparecen cargados a la vez como lo luminoso y lo opaco, lo familiar y lo extraño, como lo que causa dolor y lo que hay que aprender a añorar/extrañar. Aunque aquellas imágenes lleven a pensar que lo siniestro se presenta como un modo de codificación restringida al imaginario infantil, en realidad, lo siniestro emerge aquí de modo más genérico, como uno de los nombres que puede asumir la experiencia del destierro. La extrañeza de lo familiar permite codificar en un sentido más amplio, la cuestión del retorno marcando un contraste con las idealizaciones del regreso y apuntando las mutaciones irreversibles que el paso del tiempo ejerce no sólo sobre el país que se abandona sino sobre el propio sujeto desplazado.

Hay también una serie de imágenes de habitaciones sin personas; naturalezas muertas deshabitadas como los paisajes naturales, pero que divergen de ellos en su estar colmadas de objetos, y donde lo que importa es la disposición de esos objetos, que remiten a espacios domésticos, familiares: el modo en que la ropa se sale de un cajón, una cama deshecha, cassettes en una repisa, zapatos amontonados, cuchillos dispuestos en la cocina, juguetes. Mientras se ven estas imágenes, escuchamos que la voz dice: "parece que las cosas a media luz son de otra persona". Acogiéndonos al pacto ficcional sobre el personaje que propone la película, aquella frase distancia los objetos del hogar cargados de la experiencia vivida, que parecen ahora desplazados, extraños, fracasando en la función restitutiva que de ellos se espera, como si se desintegrara la capacidad de posesión (Avelar, 2000) de quien rememora- Incluso el hogar (el refugio ante la 
catástrofe) parece entonces extraño, esos objetos ya no pueden sino "parecer de otra persona".

\section{Anclajes históricos}

La voz femenina que escuchamos a lo largo de la película, no entrega información de contexto, no menciona fechas, personajes históricos, ni hitos coyunturales específicos. Se trata de un relato íntimo que busca retener la perspectiva de la infancia para descifrar el presente, y en el cual los episodios históricos aparecen de forma descentrada, montados dentro de la temporalidad personal. La película de Rossi deja hablar a los registros radiales y fragmentos de archivos televisivos, lo que no quiere decir que se los presente como evidencia irrefutable de lo que sucedió, si no que se los enlaza poéticamente a partir del montaje sin necesidad de mayor explicación o contextualización por parte de la voz que narra.

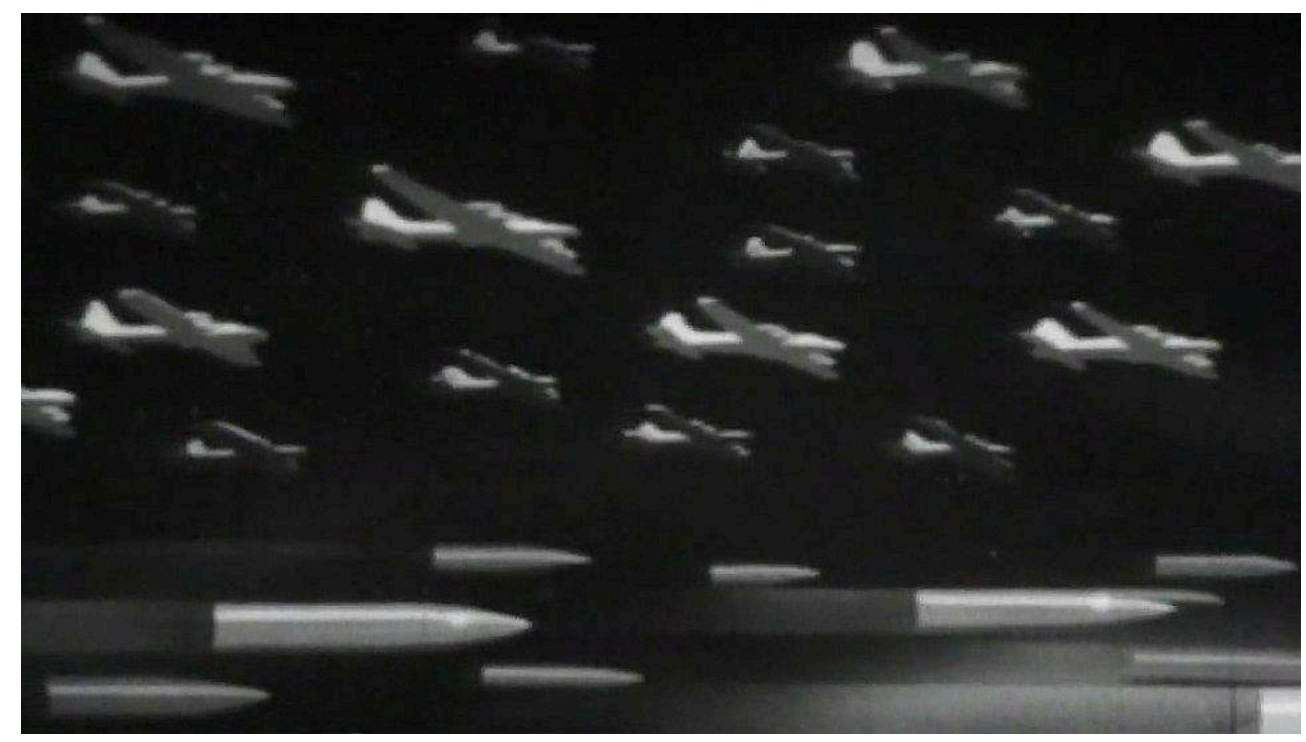

El trabajo sobre el documento histórico está presente a lo largo del film desde un primer momento, dando a lo sonoro un lugar privilegiado, con las voces del golpe. El film comienza con la pantalla en negro, en tinieblas, sobre la que escuchamos el sonido de la comunicación por radiocomando, llena de interferencias, entre Augusto Pinochet y los militares que arremeten La Moneda tras la muerte de Salvador Allende. Más adelante, casi junto con la inscripción del título del film, se introducen otros dos registros sonoros: el bando militar $n^{\circ} 5$ transmitido por radio por una voz anónima el mismo 11 de septiembre de 1973 y a continuación, un audio que nos permite escuchar la voz del dictador justificando la política de extradición de la dictadura.

31 Frente a imágenes emblemáticas del golpe de Estado como el bombardeo en la Moneda, Rossi privilegia el encuadre sonoro de la voz autoritaria ${ }^{13}$, que al sustraer la imagen, funciona en el registro de lo secreto y lo siniestro (una de las formas en que la lengua materna se torna extraña, atemorizante y cautivante a la vez). Por un lado, el bando militar, esa voz militar anónima desanclada de la letra de la ley que se impone a si misma como fuerza de ley anulando el orden constitucional, convirtiendo en ese acto a toda la sociedad en un gran cuartel ${ }^{14}$. Y por otro, la voz nasal y aguda del dictador, uno de los soportes libidinales de la dominación autoritaria y única voz que a lo largo del 
film pronunciará la palabra exilio, subrayando su propia omnipotencia ubicándose discursivamente el lugar de $\operatorname{Dios}^{15}$.

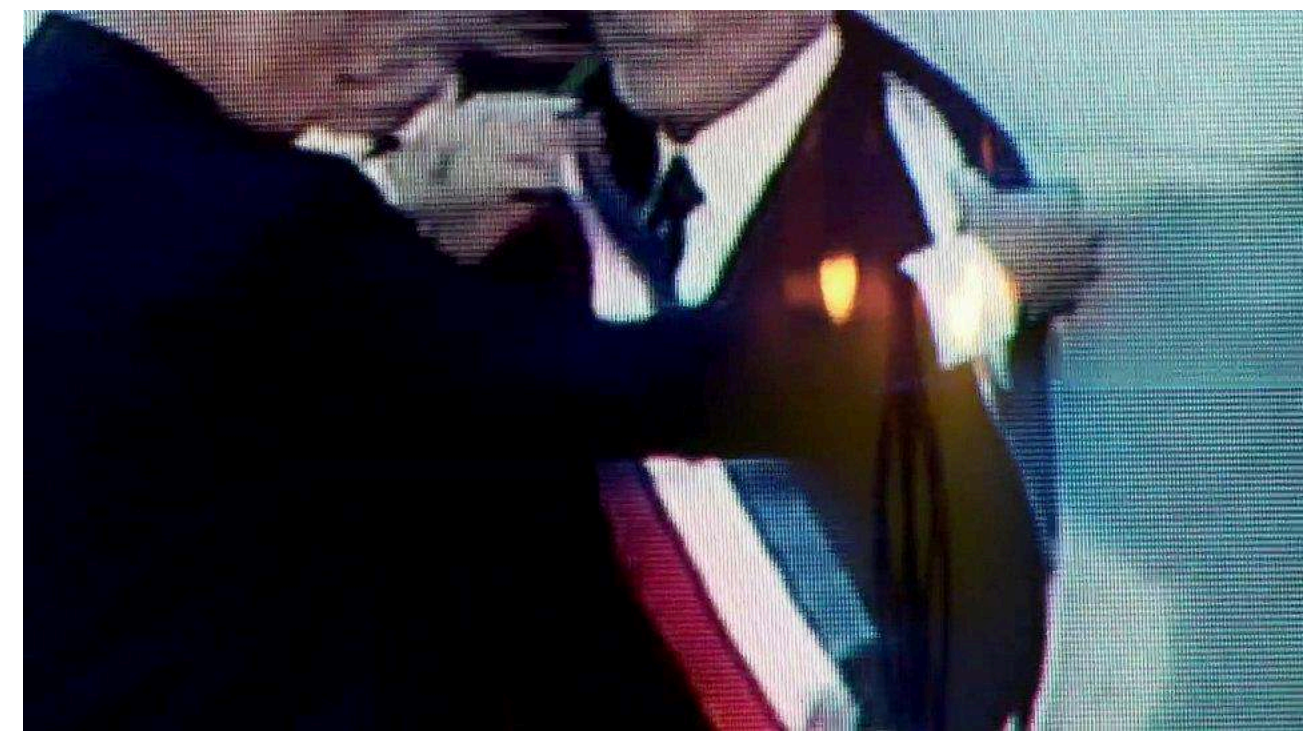

Arriba señalábamos que la figura de la catástrofe, no sólo funciona en la película como la imposibilidad de restituir el territorio como paisaje, sino que también como clave de lectura histórica. Los documentos históricos que vemos en el film no (solo) marcan hitos de una cronología emblemática de la dictadura (las jornadas de protesta a partir de 1983, el terremoto del 1985, el atentado a Pinochet en 1986, el plebiscito en 1988). Es como si en el imaginario infantil, la fuerza telúrica del accidente natural que irrumpe violentamente arrasándolo todo, encontrara equivalencia en ciertos hitos históricos que desestabilizaban el control militar durante el período dictatorial adquiriendo magnitud de catástrofe. La mirada del film, pareciera por momentos ser una mirada en conflicto dividida entre el deslumbramiento y el terror frente a la fuerza de la catástrofe que fractura e interrumpe de modo incalculable e irreversible el orden de las cosas, pujando a transfigurar el punto de vista y de enunciación ${ }^{16}$.

Así, en ocasiones, como operando en el registro de lo sublime, las imágenes de desastre se enlazan de modo que el poder que manifiestan ciertos accidentes naturales como la fuerza del viento o el ímpetu de una tormenta, parecen guardar la misma conexión con el terror que el poder institucionalizado ostentado por un régimen autoritario. La omnipotencia del dictador ${ }^{17}$, aparece ante la mirada infantil como cacique inderribable, que bajo el alero divino sortea el atentado contra su vida ${ }^{18}$ (la virgen del perpetuo socorro lo "mantuvo intacto"). Distintos archivos de época nos muestran señales de hostilidad: las palabras amenazantes que Pinochet dice ante las cámaras tras el frustrado ataque, la declaración de estado de sitio, el discurso oficial que atribuye el atentado a extranjeros/exiliados. A continuación, la voz cuenta un sueño de la niñez que imagina la represalia de un poder omnipresente, amparado por la figura religiosa de la virgen que transforma su alero protector en asedio amenazante: "En la noche soñé con mi familia muerta en el patio. La virgen flotaba sobre ellos". Simultáneamente, vemos la imagen de la mano de un cadáver cubierto con un plástico negro que se asoma inerte sobre el pasto mientras se escucha el sonido del viento. Enseguida, el relato de la voz continúa con el viaje de vuelta a Roma que coincide en la narración con el desastre de Chernóbil, la explosión nuclear retenida en imágenes de una gran nube de polvo que avanza arrasadoramente disolviendo todo a su paso. De ese modo, la catástrofe 
pareciera encontrarse tanto en el lugar del que se fue desterrado como en el lugar al que el destierro conduce y ambas imágenes (el tiranicidio frustrado, el accidente nuclear) parecerían desdoblarse la una en la otra como el desastre desatado ante la falla humana o lo incalculado.

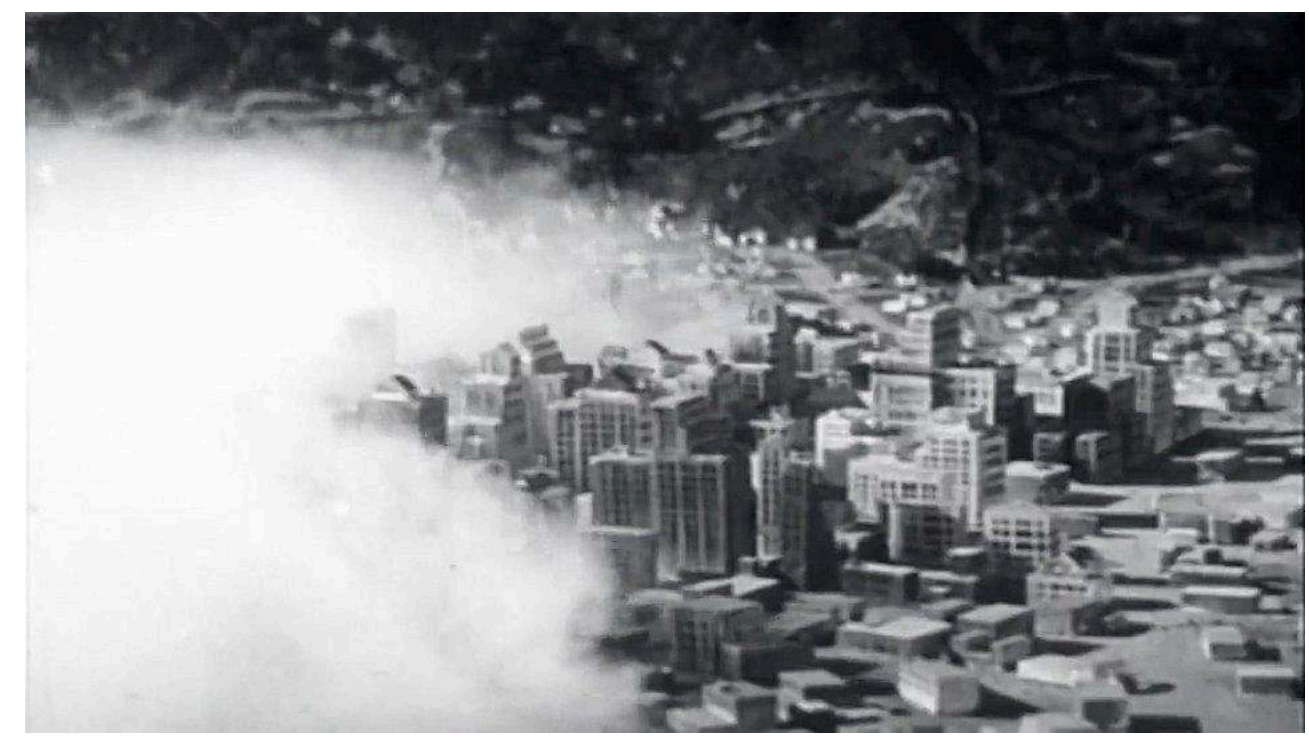

Ahora bien, en la medida en que aquellas imágenes tempestuosas se basan en nuestro contacto con la realidad física, "las metáforas del viento y la tormenta sugieren [pueden sugerir] que la mente es impotente para interferir en los procesos sociales y que por consiguiente estos procesos obedecen a leyes que no pueden ser manipuladas" (Kracauer, 2010: p.70). Podría pensarse en efecto que la catástrofe como modelo del surgimiento de nuevas estructuras sociales y simbólicas, tenderían a una naturalización de la historia. Pero es interesante que en la película, las imágenes deshabitadas de la naturaleza desencadenada, cohabitan con la historicidad de un conjunto de imágenes donde aparece el pueblo en movimiento, una masa que no se debe a ningún líder excepcional, congregada en torno a la épica de derrocar al régimen.

Se trata de material de cámara que no enfoca a los grandes personajes, sino que, como señala Ranciere a propósito de los usos documentales de la fotografía y el cine, "fijan puntos de luz sobre existencias hundidas en el anonimato" (Ranciere, 2004: p.163). Un anonimato, en este caso, desdoblado en la fuerza de la multitud y la imperceptibilidad del excluido. Por ejemplo, mientras se escucha el discurso prohibitivo de un bando militar ("cualquier acto de sabotaje en todo tipo de actividades nacionales, como empresas, fabricas, medios de comunicación o de transporte, será sancionado de la forma más drástica posible el lugar mismo del hecho"), vemos la desobediencia de grupos interminables de hombres, mujeres y niños gritando y aplaudiendo mientras salen del metro hacia una concentración pública. A continuación se escucha la consigna "pan, trabajo, justicia y libertad" vociferada por una voz colectiva, y más adelante, escuchamos fragmentos del último discurso de Salvador Allende mientras vemos imágenes aéreas de hordas de personas ocupando del parque O’Higgins para manifestar su rechazo al régimen dictatorial. La masa movilizada, las voces unificadas en la repetición de una consigna, se singularizan cuando vemos un grupo de trabajadores, quizás funcionarios públicos, que rodean a un hombre de pequeña estatura que grita a voz alzada interpelando a Pinochet: "váyase, Chile no lo quiere" (minuto 21:30) ${ }^{19}$. 


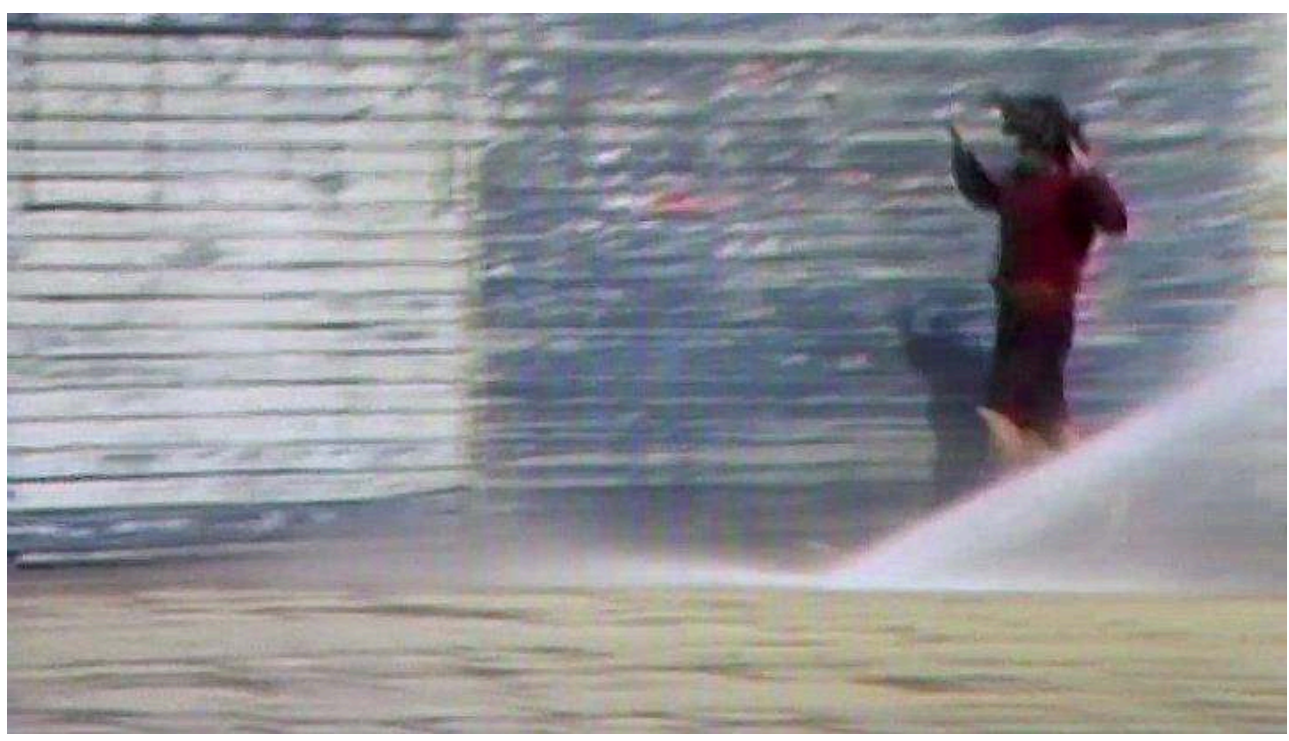

\section{El último paisaje}

Por último, es interesante observar cómo aparece la figura del retorno -que desde cierta perspectiva- cerraría el círculo del exilio. En la narración, el momento del regreso a Chile es indicado por el fragmento de un archivo televisivo que muestra a Jaime Guzmán ${ }^{20}$ anunciando la medida oficial que da de baja la extradición prolongada a un conjunto de chilenos. Paradójicamente y en contraste con una mirada conciliadora del retorno, el montaje muestra nuevas imágenes del destierro: la imagen de Guzmán se funde a la imagen de un cohete que asciende hacia el espacio exterior, y luego a la imagen de unos árboles arrancados del suelo por el viento. De este modo, el viaje de regreso se prefigura como desarraigo, como el viaje a un espacio tan extraño como el espacio exterior, un espacio extra-terrestre. A continuación, vemos la imagen de un paracaídas que cae-como imagen emblemática del irrumpir en una situación sin contexto-fundiéndose sobre un mapa de Chile. También conforma esta serie de imágenes, una tormenta que golpea la embarcación de Gulliver, el navegante "que viaja por lugares cada vez más extraños" ${ }^{21}$, cuyo barco se despedaza entre las olas haciendo reaparecer la imagen del naufragio a la que aludimos al principio. Es decir, aparece el retorno como naufragio, como si el retorno fuera en realidad una nueva salida. En una estructura especular, salida y retorno se revelan así indiscernibles.

Esta figura especular nos permite recordar en este punto la etimología de la palabra exilio. Según Jean Luc Nancy, ésta nos ha sido transmitida con equívocos. En principio se la remitía a la conjunción ex - solum, que querría decir, literalmente, privado o arrancado de su suelo. Las imágenes de animación que muestran el viento arrastrando violentamente las cosas, desprendiendo árboles del suelo desde sus raíces, haciendo volar casas hasta dejar desnudos a sus habitantes, o aquella de la caravana árabe arrancada del desierto que avanza agarrada "a un hilo de polvo" por paisajes inusitados (el espacio exterior, un paisaje lluvioso) establecen ritornelos al reiterarse una y otra vez en el film, y dan en efecto, forma sensible a esa figura del desarraigo. 


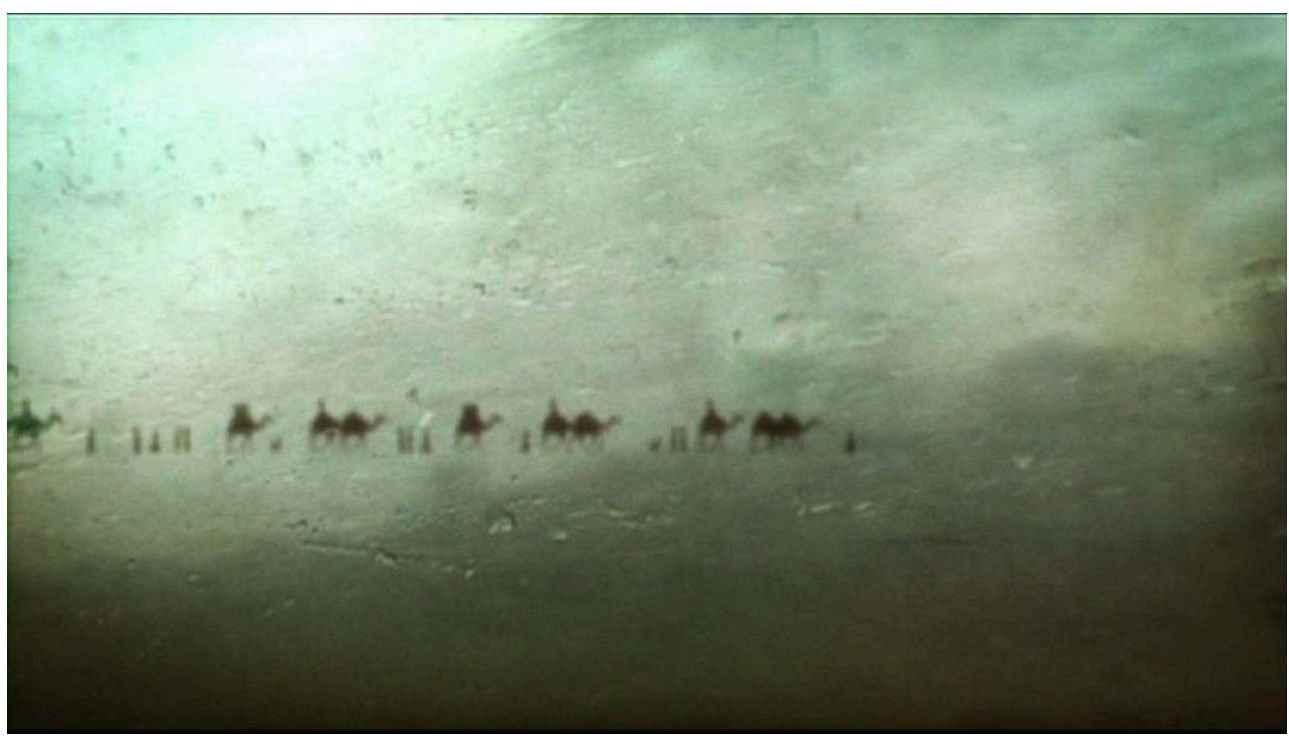

Otra figura relevante en este sentido es la del secuestro como manera de ser sacado de lo propio. Mientras vemos la imagen de una película en blanco y negro que muestra a dos fascistas que descienden de un platillo volador (y que puede ser leída como peligro de abducción), la voz dice: "Imaginaba que me iban a secuestrar. Sin ningún recuerdo me devolverían a un bosque sin luz. Desde ahí comencé a guardar, archivar toda clase de pistas para volver". El secuestro aparece también como amenaza en otras imágenes: un auto que espera cada día a la salida de la casa de los abuelos, o las imágenes de un helicóptero que avista desde el aire. Así, la urgencia de atesorar recuerdos que como las migas de Hansel y Gretel servirían como pistas para volver, aparece como presentimiento de un peligro irreversible: el secuestro de la memoria. Éste puede leerse como operación siempre acechante de todo discurso reconciliatorio, oficial, de izquierda o de derecha. Pero sobre todo y con mayor fuerza, el secuestro de la memoria como peligro, como el destierro más amenazante, o más aún, como la figura del destierro definitivo.

Y sin embargo, Nancy advierte que en realidad, la palabra exilio proviene del vocablo ex - sul, donde sul, es la raíz de una serie de palabras que significan "ir", dando cuenta de la acción de salir sin un destino predeterminado, de modo que el exiliado sería "el que parte absolutamente" (Nancy, 2001), y que por lo tanto, lleva a cabo un proceso de arrancamiento, una ex - propiación extrema. Retomando esta segunda etimología Jean Luc Nancy propone pensar el exilio como asilo; en el sentido de que sería una forma de lo propio, un modo particular de refugio. Desde esta perspectiva, el exilio no es concebido como una persistencia ni como una valoración sin más de la errancia. Se trataría de una experiencia que no se puede desandar, llegando a constituir una forma de existencia, una forma de lo propio entendido como una propiedad de extrañamiento. En sus palabras, "el yo como exilio, como apertura y salida, salida que no sale del interior de un yo, sino un yo que es la salida misma" (Nancy, 2001, el subrayado es mío). Esto configuraría una particular relación con lo propio que no está ya atado a las figuras del origen que mencionábamos al comienzo (lengua, territorio, sangre), sino a la idea aporética de la expropiación y el extrañamiento como propiedad y pertenencia. De modo que, paradójicamente, lo que puede plantearse es que si hay algo de lo cual el desterrado no puede ser expropiado es de su exilio como despojo inicial, de modo tal que en el propio exilio hay una posibilidad de que el sujeto pueda estar al abrigo. 

imágenes de la película que muestran filmaciones recientes de Chile. Como el episodio que impulsa retroactivamente todo lo que acabamos de ver y escuchar, las escenas de las calles santiaguinas tras la muerte de Augusto Pinochet, muestran como los fervores del pasado vuelven a despertarse como si el tiempo hubiera rebotado. A partir de aquí, la secuencia final de imágenes del film señala el equívoco que sería comprender el exilio como un intervalo que se abre y se cierra con la dictadura. La cuestión del exilio como salida, se actualiza al final del film como huella y resonancia que persiste. Por una parte, vemos secuencias de imágenes contemporáneas de Italia, en las que el movimiento de la diáspora se actualiza como diáspora económica determinada geopolíticamente, desdoblada en el migrante africano y su reverso, el turista asiático.

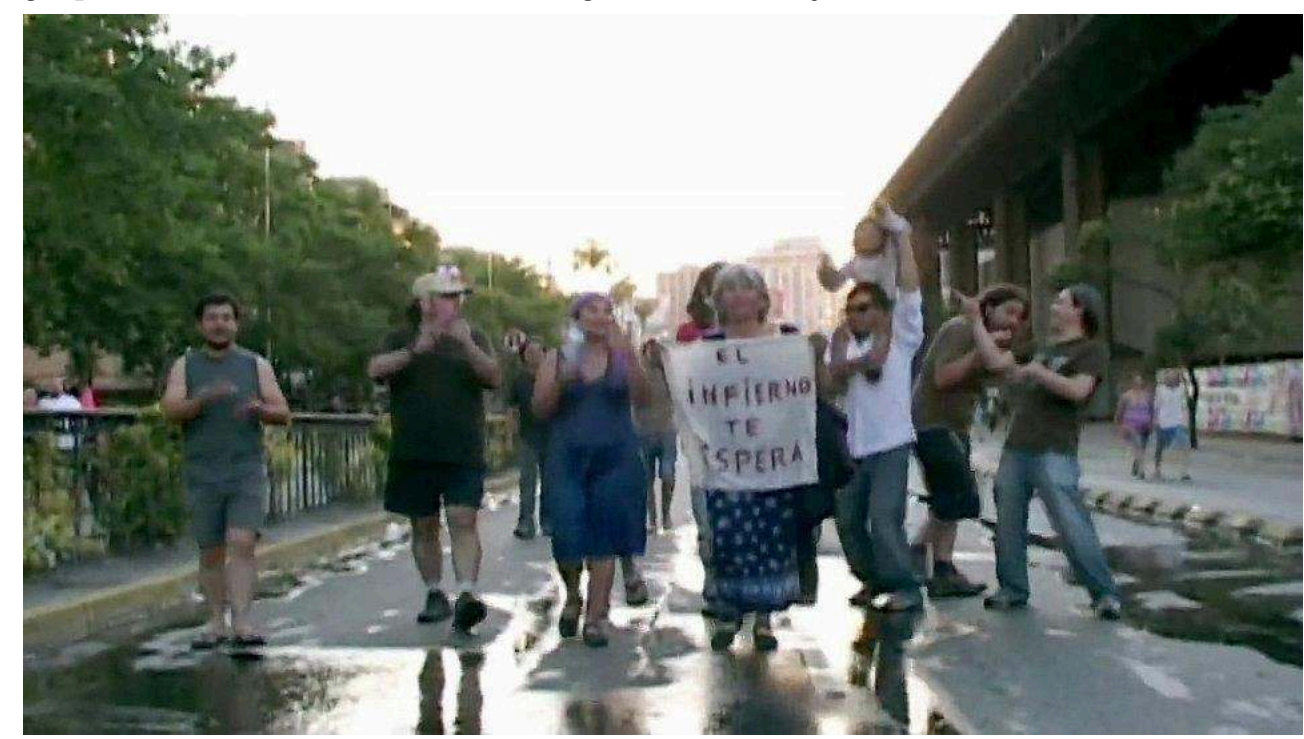

Pero sobre todo, el exilio como persistencia se materializa en las imágenes finales de territorios que, una vez más, borronean las marcas de un lugar geográficamente identificable. La pantalla otra vez se despuebla y nos hace transitar por paisajes o estados de la materia: imágenes de un mineral en fundición, una tormenta de nieve, un paisaje marítimo, un territorio ventoso. Simultáneamente, la voz fabula sobre el nuevo comienzo de un viaje $\mathrm{e}^{22} \mathrm{y}$ vemos nuevamente la imagen de un barco. El viaje romántico, la navegación como espacio biográfico y el lugar propio como embarcación, es convertida por el film en imagen primordial del exilio como salida. En efecto la voz habla de la cuna (que es otro nombre para la patria) "como una barca meciéndose en el mar"23. Parece entonces significativo que la imagen final de la película sea la imagen del mar, que puede ser pensada como imagen arquetípica del espacio marítimo como superficie sin fronteras ${ }^{24}$, algo así como una matria ${ }^{25}$ que podría emerger como regazo acuático, reverso de la patria como lugar de lo propio, que pertenece al universo de la tierra firme, de la superficie terrestre con su cartografía de naciones y delimitaciones territoriales que necesita, entre otras, de la figura del exilio para ratificar sus fronteras. 


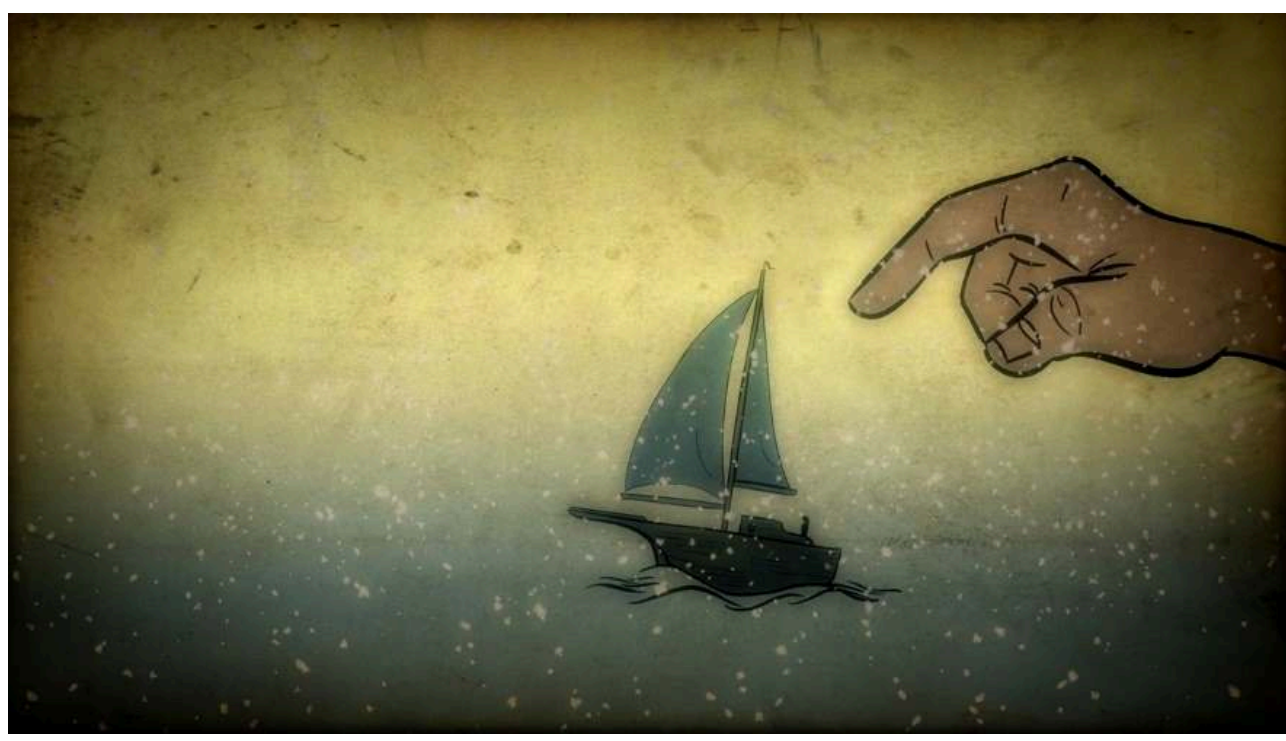

Al mismo tiempo, en el relato del film, el viaje y el mar abierto es también una imagen activada por un evento histórico anclado en una situación precisa: la muerte de Augusto Pinochet. El cadáver del dictador (que muere antes de ser juzgado) no implica un cierre ni la llegada de la reparación, sino que más bien reaviva tensiones y hostilidades del pasado. Funciona a la vez con la fuerza de la atadura y la de la expulsión. En realidad, podría pensarse que la última imagen de la película no implica desplazamiento sino quietud: es casi una posición de la mirada, pues la cámara gira dejando ver un pedazo de tierra hasta perderse en el mar. Esa mirada hacia el mar parece entonces hablar del exiliado como aquél que queda de espaldas al territorio, de espaldas a la patria. Esta sería la singularidad de esta mirada generacional. No es una visión frontal, anhelante del que retorna a recuperar lo perdido, ni tampoco la negación o el abandono del que da la espalda. Es el que queda de espaldas como una forma de pertenencia, la mirada en fuga del que sólo puede habitar la patria desde una posición incómoda, no reconciliada, el que queda ahí ocupando un lugar molesto, pues subraya el carácter ficcional de la reconciliación y la unidad.

El eco de las canciones recoge retazos de imágenes que han sido descartadas como ruinas, como desechos históricos que cargan consigo las alquimias de la catástrofe, mostrando que a partir del extravío de la historia es posible la reinvención a partir de la pérdida. La reinvención-del territorio, de la biografía, del pasado-parece aquí una tarea no acabada por la que nos conduce una voz sin dueño, una subjetividad fabricada a partir de múltiples ecos.

Por otra parte, en contraste con los discursos de la reconciliación tanto como con los que inmovilizan el trauma bajo la figura de la víctima o el héroe, El eco de las canciones sugiere que hacer memoria del trauma no implica su superación ni tampoco, quedar en todo momento adherido al dolor. Nos insinúa que no quedar fijado al dolor no implica excluir la necesidad de justicia ni haber hecho aquello que llamamos "trabajo de duelo". Al contrario, parece sugerir que no serpia posible un cierre definitivo del trauma y del duelo ${ }^{26}$, así como tampoco, aún con la consumación física del retorno, habría un cierre del exilio. 

como excluyentes los procedimientos en fuga de la imaginación y la severa realidad de la violencia política y de las violencias de la intimidad. Y que es necesario un riguroso trabajo de redistribución de las fuerzas de la palabra y de la imagen, para que las imágenes botadas de la historia ${ }^{27}$ puedan trastornar los lenguajes y de ese modo, la realidad.

\section{BIBLIOGRAFÍA}

AGAMBEN, Giorgio (2000). 'Política del exilio'. En: Identidades comunitarias y democracia. Edición de Héctor C. Silverio Gorski. Madrid, Trotta.

AVELAR, Idelver (2000). Alegorías de la Derrota. La ficción postdictatorial y el trabajo de duelo. Santiago, Cuarto Propio.

CASTILLO, Gabriel (2003). Estéticas Nocturnas. Ensayo republicano y representación cultural en Chile e Iberoamérica. Santiago, Ediciones Estética UC.

GROYS, Boris (2008). "El arte en la era de la biopolítica. De la obra de arte a la documentación de arte”. En: Obra de arte total en Stalin: Topología del arte. Centro Técnico Cultural, La Habana, p. 165-183.

KRACAUER, Siegfried (2010). Historia. Las últimas cosas antes de las últimas. Las cuarenta, Buenos Aires.

NANCY, Jean Luc (2001). “La existencia exiliada”. En: Revista de Estudios Sociales n8, Bogotá, Colombia. Disponible en: http://redalyc.uaemex.mx/src/inicio/ArtPdfRed .jsp

$?$ iCve $=81500813$

MARTINIC, Mateo. Archipiélago patagónico, la última frontera. Ediciones de la Universidad de Magallanes, Punta Arenas, Magallanes, 2004.

RANCIERE, Jacques (2004). "Lo inolvidable”. En: Pensar el cine 1. Gerardo Yoel comp. Buenos Aires, Manantial.

RANCIERE Jacques (2005). "La ficción documental: Marker y la ficción de la memoria”. En: La fábula cinematográfica. Barcelona, Paidós. 
REBOLLEDO, Loreto (2006). Memorias del Desarraigo. Santiago, Catalonia.

VAN ALPHEN, Ernst (2009). “Hacia una nueva historiografía: Peter Forgacs y la estética de la temporalidad”. En: Revista de Estudios Visuales nº. Disponible en: http://estudiosvisuales.net/ revista/pdf/num6/alphen_EV6.pdf.

\section{NOTAS}

1. "Violencias de la intimidad". Comentario publicado en: http://blog.lucysombra.org/2010/10/ el-eco-de-las-canciones/

2. Al comienzo del film la voz señala: "reconocer lo que ha quedado oculto en el tiempo. Pero inventando me paso la mayor parte de los días. La fuga es tan poderosa que no he querido dejarla" (minuto: 9:08).

3. Una señal de este descalce es la heterogeneidad del material de archivo ensamblado. También lo es la ausencia de un repertorio de imágenes de los "personajes" del film que los muestre en distintas situaciones o ejecutando acciones. Antes bien, tal como sucede por ejemplo con el primer plano de una niña que mira a la cámara y que la voz identifica con la imagen de su hermana y a la que nombra "Juana", se trabaja sobre imágenes inmóviles de un personaje que se singulariza y a la vez se despersonaliza tornándose casi icónico, lo cual acentúa por otra parte, el estado onírico de su aparición. En la misma línea, la introducción de fotografías familiares dan consistencia al relato de la voz sin particularizar rostros ni lugares y a la vez, nos hablan de los procedimientos de la memoria, pues se trata de imágenes fijas que muestran personas a las que el encuadre fotográfico ha recortado las cabezas, o imágenes en velocidad que parecen cuadros impresionistas, de modo que obligan a completar lo sustraído, tal como sucede con los recuerdos.

4. Ver; Violencias de la intimidad, Op.cit.

5. De ahí también que Rebolledo hable de esta idea del exilio como un paréntesis.

6. El eco de las canciones, minuto: 10:45.

7. "Sabemos que en el extremo norte, Chile está separado del mundo por una ancha extensión desértica. Por el sur, mira hacia los hielos del polo, por el oeste, tiene el océano hasta la mitad del mundo y por el este, la cordillera inmensa. Un país así se llama isla, aún cuando sus limites no encuadren dentro de la definición geográfica de las islas" (Castillo, 2003: p. 107)

8. Por ejemplo, en su estudio sobre los ensayistas chilenos de la primera mitad del siglo XX, Gabriel Castillo incluso sugiere que esta inminencia de la catástrofe opera en cierto sentido como sustituto del carnaval: "La sociedad local no requiere de un accidente a su orden de una válvula festiva pero regulada de escape a la coherencia habitual de las relaciones sociales, como ocurre en la sociedad europea. En la inminencia del gran desastre y en la persistencia real de la incoherencia la sociedad chilena busca instaurar un principio ordenador pero superficial" (Castillo, 140).

9. Sería interesante profundizar esta figura a partir de la obra de Bernardo Subercaseaux "Chile, una loca geografía".

10. Corominas, 2000 , p. 335

11. Girogio Agamben: "el exilio es refugio, a saber: ni derecho ni pena (...) el exilio parece rebasar tanto el ámbito luminoso de los derechos como el repertorio sombrío de las penas y oscilar entre el uno y el otro" (Agamben, 2000).

12. Otra escena de reunión familiar, aparece en lo que la voz cuenta como primer viaje a Chile. Nuevamente aparece ahí la mirada a la cámara en la divertida mueca que un hombre adulto hace a la cámara. Pero quizás lo más perturbador de la secuencia es el desvío de la cámara que enfoca a una trabajadora del hogar, quizás como un comentario político de la mirada exiliada, respecto a las contradicciones de clase del espectro de la izquierda. 
13. Cuestión que ya había sido trabajada de modo similar por Betina Perut e Ivan Oskovnikof en "El astuto mono pinochet y la moneda de los cerdos" (2004).

14. Los bandos militares son edictos propios del Código militar cuya principal función es disciplinar a las tropas. La constitución de 1925, vigente al momento del golpe, no los reconocía como fuente de derecho, sin embargo, los militares golpistas los utilizaron en los años previos a la imposición de la nueva constitución, como soporte ideológica, informativo-propagandístico y normativo-institucional del régimen. Hemos trabajado este tema en el texto: "La voz autoritaria. Notas sobre voz, teatralidad y poder". Carvajal”. En: “Teatralidades Latinoamericanas. Teorías, prácticas y contextos" (En prensa).

15. Escuchamos la voz de Augusto Pinochet diciendo: "Ellos fueron malos chilenos, quisieron vender a su patria, y quieren entregarnos como colonia a los rusos, y lógicamente debían ser castigados. Cuando dios se irritó y lanzó a los demonios al infierno, ¿no fue una extradición? ¿No fue un exilio?".

16. En efecto, el tratamiento de la catástrofe en el film adquiere un semblante que podría ser leído desde el concepto de lo sublime.

17. En otras ocasiones, las personalidades del régimen aparecen interpeladas por escenas más burlescas y desacralizantes. Así sucede en la secuencia que muestra el preámbulo del plebiscito que pondrá fin, al menos en los hechos, a la dictadura. Primero vemos la imagen de Lucía Hiriart dando un discurso desde el balcón de La Moneda. Mientras seguimos escuchando sus palabras, se introduce una imagen de animación que muestra a una mujer pomposa a la cual unos pájaros le desarman el peinado, mientras las figuras de su entorno se derriten, imágenes que funcionan como premonición de la decadencia e inminente caída de las autoridades de la dictadura. Luego, el archivo televisivo de una entrevista de la periodista Noelia Miranda a Pinochet en que ésta "sencillamente" le pregunta al dictador si le gusta el poder. Éste responde: "Sencillita la pregunta, muy sencilla. Mire, el poder lo acepto como una necesidad para poder gobernar. El poder por poder no me gusta". El pasaje es de por sí de una ironía por lo burdo del diálogo, lo cual se ve reforzado por la imagen a continuación, en la vemos una animación que muestra el ancla de un barco que rescata desde el fondo del mar un soldado que escupe agua. La imagen puede ser leída, como subrayado del "rescate" mediático que en el contexto del plebiscito, está implícito en la entrevista evidentemente pautada. O bien el escupo puede interpretarse como signo de desprecio e irrespeto hacia el dictador, como el gesto -característico del insulto italiano- que corona una maldición.

18. Nos referimos al atentado que el Frente Patriótico Manuel Rodríguez realiza a Augusto Pinochet en septiembre de 1986.

19. También aparecerán grandes masas en las imágenes que muestra el contexto del plebiscito, filas de votantes en un país que durante 17 años no tuvo elecciones y luego, miles de personas celebrando en las calles el triunfo de la opción "no" que sacaba en los hechos, a Pinochet del poder.

20. Político de la Unión Democrática Indpendiente (UDI), considerado uno de los principales ideológos de la dictadura. Abogado de profesión, dio forma jurídica a la Constitución de 1981 impuesta por la dictadura y aún vigente en Chile.

21. Entrevista personal realizada por la autora a Antonia Rossi en Marzo, 2011.

22. "Pienso en el último viaje casi borrado por una tormenta de nieve. Por el sillón se desliza un reflejo que no puedo imaginar de donde viene. Hay miles afuera y que nos son de ninguna parte. Hacia los atardeceres cae agua y nieve sobre el océano. Cargo todas las fotografías y los sonidos. Llueve en todos lo pasadizos. Todos los caminos se mojan. Las imágenes y las canciones se deshacen. Los atardeceres eran así en la cubierta del barco, adivinando el sonido de la lluvia sobre la tormenta".

23. El eco de las canciones, min. 10:12.

24. También el desierto, otra de las figuras recurrentes en el film, puede funcionar de este modo. 
25. Tomo el término "matria" del crítico Ricardo Loebell quien propuso este sentido del término en una ponencia sobre el escritor chileno Augusto D’Halmar en la Escuela de Danza de la Universidad Mayor en mayo del 2011.

26. Tomamos aquí la noción de duelo presente en los escritos de Jacques Derrida, quien plantea que la pérdida no se puede resolver ni trabajar, a lo más se reprime, incorporándola por negación. En realidad, para Derrida lo que existe es un duelo "imposible", que mantiene lo perdido como un otro en mí. Presupone por tanto que nuestras pérdidas nos constituyen y permanecen con nosotros encriptadas, bajo la forma de aquello que no está ni vivo ni muerto, es decir, en condición de espectro. La espectralidad impide la introyección de la otredad al modo del "trabajo de duelo" que fagocita al otro y "transfiere" el deseo a "otro objeto", sino que, como señala Cragnolini, deja en suspensión a lo que ya se halla en ese modo: el fantasma, la posibilidad de constituir en mí al otro a la vez vivo y muerto. Ver: Cragnolini, Mónica B. "Para una 'melancología' de la alteridad: diseminaciones derridianas en el pensamiento nietzscheano. Disponible en: http://www.jacquesderrida.com.ar/comentarios/derrida_nietzsche.htm\#_edn11 27. Entrevista personal realizada por la autora a Antonia Rossi en Marzo, 2011.

\section{RESÚMENES}

Este articulo analiza las operaciones de desfiguración sobre las imágenes emblemáticas del exilio político durante la dictadura, puestas en juego en el documental El eco de las canciones (2010) de Antonia Rossi. En los últimos años se han publicado diversos trabajos sobre el giro autobiográfico del documental contemporáneo, atendiendo las articulaciones entre memoria subjetiva e historia y a las hibridaciones entre realidad y ficción que éste presenta en sus diversas manifestaciones. Enmarcándose en esa línea de trabajo, el presente artículo busca no solo abordar las imágenes correspondientes al universo de lo íntimo, la infancia y lo familiar, si no también un aspecto aparentemente marginal: se trata de examinar cómo las imágenes de la naturaleza y la catástrofe natural logran trastornar la relación pacífica y continua entre exilio, identidad y territorio. De este modo, indagaremos cómo aquellas operaciones de deformación del imaginario, producen una noción extrañada de identidad, atravesada por una alteración decisiva de relación entre lo propio y lo ajeno.

C'est à partir du film documentaire d'Antonia Rossi El eco de las canciones(2010) que nous analyserons, dans cet article, les modes de transformation des images emblématiques de l'exil politique pendant la dictature chilienne. Divers travaux portant sur la tendance autobiographique du documentaire contemporain - plus particulièrement sur les rapports entre mémoire subjective et histoire d'une part, et les hybridations entre réalité et fiction d'autre part, - ont été publiés au cours des dernières années. L'article cherche à examiner, dans cette perspective, un aspect qui semble marginal: comment les images de la nature et des catastrophes naturelles, associées à celles de l'univers de l'intime et de l'enfance, parviennent à troubler la relation pacifique et durable entre exil, identité et territoire dans le film de Rossi. Nous essayerons d'analyser les raisons de la transformation de l'imaginaire sur l'apparition d'une autre notion d'identité traversée par une altération du rapport entre ce qui est personnel et ce qui est étranger (ou différent). 
ÍNDICE

Mots-clés: exil, dictature, catastrophe naturelle, identité, cinéma

Palabras claves: exilio, dictadura, catástrofe natural, identidad, cine

\section{AUTOR}

FERNANDA CARVAJAL

CONICET-UBA

fercarvajal21[at]hotmail.com 